\title{
Assessment of Metal - Induced Inhibition of Soybean Urease as a Tool for Measuring Heavy Metals in Aqueous Samples
}

\author{
Magomya, A.M ${ }^{1}$, Barminas, J.T ${ }^{2}$, Osemeahon, S.A ${ }^{2}$ \\ ${ }^{I}$ Department of chemical sciences, Federal University Wukari, Nigeria \\ ${ }^{2}$ Chemistry Department, Modibbo Adama University of Technology Yola, Nigeria
}

\begin{abstract}
Inhibition of soybean (Glycine max) urease by heavy metal ions has been investigated with a view to developing a method for the indirect determination the heavy metals. Urease activity was assayed as a function of metal concentration in the presence of $\mathrm{Cd}^{2+}, \mathrm{Cr}^{3+}, \mathrm{As}^{3+}, \mathrm{Cu}^{2+}, \mathrm{Pb}^{2+}$ and $\mathrm{Zn}^{2+}$. Our results revealed concentration dependent inhibition of urease activity within the range of $0.001-10 \mathrm{mg} / \mathrm{L} \mathrm{for} \mathrm{Cu}^{2+}, \mathrm{As}^{3+}, \mathrm{Cr}^{3+}$ and $\mathrm{Cd}^{2+}$ and $0.1-10 \mathrm{mg} / \mathrm{L}$ for $\mathrm{Zn}^{2+}$ and $\mathrm{Pb}^{2+}$. The inhibitory strengths of the metals as evaluated from their IC50 values showed the following ranking: $\mathrm{Cu}^{2+}>\mathrm{As}^{3+}>\mathrm{Cr}^{3+}>\mathrm{Cd}^{2+}>\mathrm{Zn}^{2+}>\mathrm{Pb}^{2+}$. Assays for multi-metal solutions revealed similar findings as the single-metal systems but with higher inhibitory strengths. The calibration plots of \% inhibition against concentration displayed different linear ranges for the investigated metals; $\mathrm{Cu} \mathrm{As}, \mathrm{Cr}$ and $\mathrm{Cd}$ showed linearity within the range of $0.01-10 \mathrm{mg} / \mathrm{L}$ while $\mathrm{Zn}$ and $\mathrm{Pb}$ plots were linear within $0.1-10 \mathrm{mg} / \mathrm{L}$. The applicability of the assay for the quantitative determination of heavy metals was evaluated by analysing synthetic water samples and comparing the results with a standard method (AAS). T-test examination revealed $74 \%$ agreement between the two methods. The results of this study show that soybean urease can be valuable for the inhibitive determination of heavy metals in aqueous samples.
\end{abstract}

Keywords: Enzyme, Heavy metals, Inhibition soybean, urease

\section{Introduction}

In recent years, the use of enzymes for analytical purposes has gained considerable importance in the quest for simple, rapid and inexpensive methods for real-time determination of compounds that may adversely affect human health and the environment. Enzymes as catalysts make excellent analytical reagents due to their selectivity and specificity and are frequently used to determine the concentration of their substrates. On the other hand, inhibition of specific enzymatic systems is also being applied as analytical methods for the detection of toxic pollutants such as pesticides [1,2] herbicides [3] and heavy metals $[4,5]$. Heavy metal ions constitute a serious environmental problem due to their ubiquitous and non-biodegradable nature. The metals and their compounds are notable for their abundance, persistence, high toxicity and ability to accumulate in living organisms [6].The toxic effect of heavy metals on biological systems stems from their interference with the normal metabolic processes of bio-molecules. The metals tend to replace other metal groups or hydrogen atoms in bio-molecules such as proteins and enzymes to form strong and stable chemical bonds. These interactions affect the normal functioning of the molecules and in the case of enzymes can lead to inhibition or complete inactivation of catalytic properties. The inhibition of enzymes by heavy metals has attracted great attention in the area of bio-monitoring of the pollutants and many enzyme- based systems have been reported for the inhibitory analysis of heavy metal ions.

Owing to its pronounced sensitivity, urease (urea amidohydrolase, EC 3.5.1.5), has been extensively applied as a probe for heavy metal ions. The enzyme is responsible for the hydrolysis of urea into carbon dioxide and ammonia [7]. It is abundantly present in different seeds, microorganisms as well as in certain invertebrates [8]. The structure and molecular weight of urease depend on the enzyme origin. In plants, it is a hexamer that consists of six identical chains and is located in the cytoplasm [9]. In the case of soybeans, the urease enzyme plays an important role during the process of germination where the protein stored within the seed is mobilized in order to nourish the seedlings [10]. Two urease isoenzymes; a tissue-ubiquitous and embryo-specific have been identified in soybean [11, 12]. The embryo-specific urease is an abundant seed protein while the other type (called ubiquitous) is found in lower amounts in vegetative tissues. The sensitivity of urease to heavy metal ions is due to the presence of multiple cysteine residue of which one, conserved principally to all known ureases, is located in the mobile flap of the enzyme active site [13]. Heavy metal ions inhibit the catalytic activity of urease by binding with a sulfhydryl group in the active center of the enzyme in a reaction analogous to the formation metal sulphides [14]. Once the metal atom is bound, the sulfhydryl group cannot function in catalysis hence there will be a marked decrease in the catalytic activity. Since very low ratios of inhibitor compounds to enzyme molecules can have a dramatic effect on the enzymatic activity, the indirect determination of trace concentrations of the inhibitor is possible by monitoring the enzymatic activity. This study is aimed at investigating the inhibitory effects of selected heavy metals on G. max urease with a view to 
evaluating its usefulness for the inhibitive determination of the metal ions. Although Soybean seeds are known to be an important source of urease, there a dearth of information on its use in enzyme - based analytical systems. This study will uncover the potential of soybean urease and provide data that will allow further exploitation in the area of heavy metal analysis.

\subsection{Materials}

\section{MATERIALS AND METHODS}

All chemicals were prepared using distilled water. The buffers used for enzyme inhibition tests were Sodium hydrogen phosphate, sodium dihydrogen phosphate obtained from $\mathrm{BDH}$ chemicals. Ammonium sulphate, Urea and sodium hydroxide were obtained from $\mathrm{JDH}$ chemicals. $\mathrm{KNO}_{3}$ was from Burgoyne, India and $\mathrm{HCl}$ from Merck, Germany. Nessler's reagent was prepared from potassium iodide (Qualikems, Nigeria) and mercuric chloride (Sigma-Aldrich). The standards for cadmium (II), Arsenic (III) and Chromium (III) were purchased as atomic absorption standard solutions $(1000 \mathrm{mg} / \mathrm{L})$ (Sigma-Aldrich). Analar grades of the salts $\mathrm{Cu}\left(\mathrm{NO}_{3}\right)_{2} .3 \mathrm{H}_{2} \mathrm{O}, \mathrm{Pb}\left(\mathrm{NO}_{3}\right)_{2}, \mathrm{Zn}\left(\mathrm{NO}_{3}\right)_{2} \cdot 6 \mathrm{H}_{2} \mathrm{O}$ from $\mathrm{BDH}$ chemicals were used to prepare stock solutions of the metals. Soybean seeds were purchased from the local market in wukari, Nigeria and the urease extracts were prepared freshly each day.

\subsection{Extraction of urease}

Powdered soybean seeds $(10 \mathrm{~g})$ were soaked overnight in $100 \mathrm{~mL}$ extraction buffer $(0.2 \mathrm{M}$ sodium phosphate buffer $\mathrm{pH} 7.3$ ) at $4{ }^{\circ} \mathrm{C}$ (Refrigeration temperature). The mixture was sieved through four layers of muslin cloth and the resulting filtrate was centrifuged at $4000 \mathrm{rpm}$ for 30 minutes. The clear supernatant was collected and used as the crude urease extract (stored at $4{ }^{\circ} \mathrm{C}$ ) while the pellets were discarded.

\subsection{Determination of urease activity}

The activity of the extracted crude urease was estimated using a slightly modified method in which ammonia released is spectrometrically determined [15]. To $0.8 \mathrm{~mL}$ of assay buffer $(0.2 \mathrm{M}$ phosphate buffer, $\mathrm{pH}$ $7.3), 0.2 \mathrm{~mL}$ of enzyme extract was added and incubated at $30^{\circ} \mathrm{C}$ with $1 \mathrm{~mL}$ of urea solution $(0.25 \mathrm{M}$ in phosphate buffer) . After 10 minutes, the reaction was terminated by addition of $1 \mathrm{ml}$ of $0.1 \mathrm{M} \mathrm{HCl}$. The reaction mixture was made up to $50 \mathrm{~mL}$ with distilled water and $2 \mathrm{~mL}$ of Nessler's reagent was added. Absorbance of the resulting solution was read against a blank at $405 \mathrm{~nm}$ on a UV-Vis spectrophotometer (APEL PD 3000). Urease activity was estimated (as $\mu \mathrm{M}$ of ammonia released) from an ammonium sulphate standard curve. One enzyme unit is defined as the amount of enzyme required to liberate $1 \mu \mathrm{M}$ of ammonia per minute under the test conditions $\left(0.25 \mathrm{M}\right.$ urea, $0.1 \mathrm{M}$ buffer, $\mathrm{pH} 7.3$ at $\left.30^{\circ} \mathrm{C}\right)$.

Urease activity of the sample was calculated using equation (1)

Urease Activity $(\mathrm{U} / \mathrm{mL})=\underline{\mathrm{A}(\text { sample }) \times \text { dilution factor }}$

$$
\text { Slope } \mathrm{x} \text { T x v }
$$

Where: $\mathrm{A}($ sample $)=$ measured absorbance of the Sample against the blank

$\mathrm{T}=$ incubation time (10 minutes for standard assay).

$\mathrm{V}=$ volume of sample

\subsection{Determination of Kinetic parameters ( $K m$ and $V m a x)$ of the extracted urease}

The kinetics of the exracted urease was evaluated using the michealis - menten model. The activity of the enzyme was studied by varying the amount of substrate (urea) from 0 to $40 \mathrm{mM}$ at constant enzyme concentration. The $\mathrm{V}_{\max }$ (i.e., maximum velocity achieved by the system, at saturating substrate concentrations and Michaelis-Menten constant, $\mathrm{K}_{\mathrm{m}}$ (the substrate concentration at which the reaction velocity is $50 \%$ of the $V_{\max }$ were estimated from the Michelis-Menten plot of reaction velocity vs substrate concentration.

\subsection{Inhibition Studies}

Standard solutions of the metal ions; $\mathrm{Cu}^{2+}, \mathrm{Cd}^{2+}, \mathrm{Zn}^{2+}, \mathrm{Cr}^{3+}, \mathrm{As}^{3+}$ and $\mathrm{Pb}^{2+}$ and multi-metal solutions with concentrations ranging from $0.001-100 \mathrm{mg} / \mathrm{l}$ were prepared by serial dilution from their respective 1000 ppm stock and their inhibitory activities were then tested on the G. max urease. In the procedure adopted for this study, $0.2 \mathrm{ml}$ metal ion solution, $0.2 \mathrm{ml}$ enzyme extract and $0.6 \mathrm{ml}$ buffer $(\mathrm{pH} 7.3)$ was allowed to incubate at $30^{\circ} \mathrm{C}$ for ten minutes to allow adequate time for metal/enzyme interaction. $1 \mathrm{~mL}$ of urea $(0.25 \mathrm{M})$ was then added and after another 10 minutes, the reaction was terminated by adding $1 \mathrm{ml}$ of $0.1 \mathrm{M} \mathrm{HCl}$. The reaction mixture was made up to $50 \mathrm{ml}$ with distilled water and $2 \mathrm{~mL}$ Nessler's reagent was added. Absorbance of the resulting solution was read against a blank at $405 \mathrm{~nm}$ on a UV-Vis spectrophotometer (APEL PD 3000). The level of inhibition for each tested metal concentration was obtained using equation (2). 
Where; Ao $=$ the obtained absorbance without the inhibitor (metal ion)

$\mathrm{Ai}=$ absorbance obtained after pre- incubation with metal ion.

A calibration graph of $\%$ inhibition against concentration was plotted for the single and multi-metal solutions

\subsection{Determination of Heavy Metals in Synthetic water Samples Using Urease Inhibition Assay}

Ten (10) synthetic water samples were prepared for each of the metals: $\mathrm{Cu}, \mathrm{As}, \mathrm{Zn}, \mathrm{Cr}, \mathrm{Pb}$ and $\mathrm{Cd}$ by adding unknown quantities of the metal solutions to distilled water. Multi-metal synthetic samples were similarly prepared by adding unknown quantities of the various metals to distilled water. All the prepared synthetic samples were subjected to inhibition assays a as described in 2.5. The concentrations of the various metals in the samples were estimated from the regression equations of the respective inhibition calibration curves.

\subsection{Determination of Heavy metals in Synthetic Samples Using Atomic Absorption Spectroscopy}

Heavy metal analysis of the synthetic water samples was done with atomic absorption spectrophotometer AA-6800 (Shimadzu, Japan). A calibration curve of absorbance against concentration was prepared for each metal by running different standard solutions of the metals and the concentrations of the samples were estimated by extrapolation from the respective calibration curves.

\subsection{Comparison of Inhibition Assay Method with Atomic Absorption Spectroscopy}

The results of the synthetic water analysis obtained via the urease inhibition assay and AAS were compared through ' $\mathrm{t}$ ' test analysis. [Components: metal type $(\mathrm{Cr}, \mathrm{Cu}, \mathrm{Cd}, \mathrm{As}, \mathrm{Zn}, \mathrm{Pb}$ and mixed metals); Methods (AAS, and spectrophotometric inhibition assay).]

\subsection{Enzyme activity and kinetic Characteristics}

\section{Results and Discussions}

The urease used in this study which was extracted from soybean (G.max) seeds revealed an enzyme activity of $15.065 \mathrm{IU} / \mathrm{mL}$. One IU (international unit) of urease activity is the amount of urease that produces 1 $\mu$ mole of ammonia from urea in one minute under the stated test conditions. The enzyme kinetics as evaluated via the michaelis - menten model showed a simple Michaelis-Menten type kinetic behaviour in accordance with what has been described for ureases from other sources. The $\mathrm{Km}$ value obtained by hyperbolic regression yielded $5.95 \pm 1.03 \mathrm{mM}$, and $V \max$ was found to be $0.45 \mathrm{mM} / \mathrm{min}$. The $\mathrm{K}_{\mathrm{m}}$ is a measure of how well a substrate complex with a given enzyme, otherwise known as its binding affinity. An equation with Low $\mathrm{K}_{\mathrm{m}}$ value indicates a large binding affinity therefore the reaction will approach $\mathrm{V}_{\max }$ more rapidly. A high $\mathrm{K}_{\mathrm{m}}$ indicates that the enzyme does not bind efficiently with the substrate, and $\mathrm{V}_{\max }$ will only be reached if the substrate concentration is high enough to saturate the enzyme. G. max urease in this study shows a higher affinity for its substrate than the ureases from B. abortus, $13 \mathrm{mM}$ [16], B. badius, 7.69mM [17] and Canavlia ensiformis, 19.10 $\mathrm{mM}$ [18] but less affinity than jack beans urease, 4.6mM [19], Phaseolus vulgaris (2.1 $\mathrm{mM})$ [20] and $H$. pylori whose urease has one of the lowest $\mathrm{Km}$ values $(0.3 \mathrm{mM})$ [21]. The findings here, suggest that the extracted urease has good affinity for the substrate (urea) under the conditions tested.

\subsection{Inhibition Studies on Single - metal solutions}

Six heavy metal ions; $\mathrm{Cu}^{2+}, \mathrm{As}^{3+}, \mathrm{Zn}^{2+}, \mathrm{Pb}^{2+}, \mathrm{Cd}^{2+}$ and $\mathrm{Cr}^{3+}$ were tested to evaluate their effects on G.max urease activity in aqueous environments. Typically the interaction of heavy metals with urease leads to decreased catalytic activity due to the binding of the metal ions with the enzyme thiol groups [14]. The results of the inhibition assays (Tables $1-6$ ) show that the metals examined in this study had different effects on urease activity. The obtained absorbances reflect the quantity of ammonia released from the catalytic activity of urease (the hydrolysis of urea to $\mathrm{HCO}_{3}{ }^{-}$and $\mathrm{NH}_{4}{ }^{+}$). The control represents the enzyme activity in the absence of heavy metals. The assay for $\mathrm{Cu}$ (II) ions (Table 1) revealed decreased responses with increased concentration corresponding to increased inhibition with increasing concentration. As can be seen, there is a dose dependent inhibition of urease activity by $\mathrm{Cu}^{2+}$ within the range $0.01-10 \mathrm{mg} / \mathrm{L}$. The data on Arsenic $\left(\mathrm{As}^{3+}\right)$ assay also established an inhibition range of $0.001-10 \mathrm{mg} / \mathrm{L} .24 .27 \%$ inhibition was observed at $0.001 \mathrm{mg} / \mathrm{L}$ concentration while $88.59 \%$ was recorded at $10 \mathrm{mg} / \mathrm{L}$. The inhibitory effect of Arsenic ions on G. max urease activity was stronger than that of $\mathrm{Cu}$ ions. This can be clearly seen from the higher percentage inhibition exhibited by arsenic at all the tested concentrations. This strong inhibition by $\mathrm{As}^{3+}$ could be due to its toxic nature. Arsenic is a highly toxic metalloid which ranks first on the Environmental Protection Agency (EPA) Priority List of Hazardous Substances [22]. Inhibition of urease by heavy metal ions has been related to its biological toxicity, which causes loss of the biological function of the enzyme [23]. Most studies published on inhibition of urease 
of both plant and bacterial origin by heavy metal ions have been aimed either at investigating their toxicity or at estimating their concentrations [24]. Arsenic ions have been shown to inactivate enzymes by reacting with the enzyme sulfhydryl groups which results in the formation of arsenic sulphide [13]. It has also been reported that $\mathrm{As}^{3+}$ decreases enzyme activity in three ways: (1) by interacting with the enzyme-substrate complex; (2) by denaturing the enzyme protein or; (3) interacting with the active protein groups [25].

Table 1: Urease Inhibition Assay for Copper

\begin{tabular}{|l|l|l|}
\hline $\begin{array}{l}\mathbf{C u}^{2+} \text { Concentration } \\
(\mathbf{m g} / \mathbf{L})\end{array}$ & $\begin{array}{l}\text { Absorbance } \\
(\mathbf{a t} \mathbf{4 0 5} \mathbf{~ n m})\end{array}$ & $\begin{array}{l}\text { Inhibition } \\
(\%)\end{array}$ \\
\hline 0.00 (control) & $1.606 \pm 0.03$ & 0 \\
0.001 & $1.416 \pm 0.02$ & 11.83 \\
0.01 & $1.313 \pm 0.11$ & 18.24 \\
0.1 & $1.252 \pm 0.04$ & 22.04 \\
1 & $1.137 \pm 0.12$ & 29.20 \\
10 & $0.202 \pm 0.05$ & 87.42 \\
\hline
\end{tabular}

Absorbances are presented as mean \pm SD for three determinations

Table 2: Urease Inhibition Assay for Arsenic

\begin{tabular}{|l|l|l|}
\hline $\begin{array}{l}\mathbf{A s}^{\mathbf{3}^{+}} \mathbf{C o n c e n t r a t i o n} \\
(\mathbf{m g} / \mathbf{L})\end{array}$ & $\begin{array}{l}\text { Absorbance } \\
\text { at } \mathbf{4 0 5} \mathbf{~ n m}\end{array}$ & $\begin{array}{l}\text { Inhibition } \\
(\boldsymbol{\%})\end{array}$ \\
\hline $0.00($ Control) & $1.718 \pm 0.04$ & 0 \\
0.001 & $1.301 \pm 0.09$ & 24.27 \\
0.01 & $1.007 \pm 0.12$ & 41.38 \\
0.1 & $0.967 \pm 0.06$ & 43.71 \\
1 & $0.889 \pm 0.11$ & 48.25 \\
10 & $0.196 \pm 0.03$ & 88.59 \\
\hline
\end{tabular}

Absorbances are presented as mean $\pm \mathrm{SD}$ for three determinations

The inhibition assay for zinc revealed some interesting findings. At the lowest tested concentration of $0.001 \mathrm{mg} / \mathrm{L}$, contrary to expectations, $\mathrm{Zn}$ ions caused an increase in urease activity. However, at the next tested concentration $(0.01 \mathrm{mg} / \mathrm{L}) \mathrm{Zn}^{2+}$ did not result in higher activation of the enzyme. The inhibition tests revealed an absorbance of 1.716 at $0.001 \mathrm{mg} / \mathrm{L}$ and $1.681 \mathrm{mg} / \mathrm{L}$ at $0.01 \mathrm{mg} / \mathrm{L}$ while the control had an absorbance of 1.652 . These values indicate higher enzyme activation at a lower concentration $(0.001 \mathrm{mg} / \mathrm{L})$ than at $0.01 \mathrm{mg} / \mathrm{L}$. The decreased activation at $0.01 \mathrm{mg} / \mathrm{L}$ suggests that partial activation and inhibition occurred concurrently at that concentration. Low concentrations of certain metal ions have been shown to enhance urease activity; Turgay and Namli, [26] reported increased urease activity at low concentrations of $\mathrm{Cd}$ and $\mathrm{Pb}$. Similar trend has also been observed with Nickel ions [27]. Our findings here demonstrate that low concentration of Zn (II) ions can enhance the catalytic activity of G.max urease. The presence of low concentrations of heavy metal ions produces stress promoters in plant cells which can lead to increased enzyme activity. As long as the stress is not too strong for the plant's defence capacity, the response to the heavy metals is an increase in the activities of certain enzymes [28]. Also, in some cases, heavy metals at low concentrations may act as cofactors and activators to enhance the enzyme activity [29]. Inhibition of urease activity by $\mathrm{Zn}^{2+}$ was observed within the range of $0.1-$ $10 \mathrm{mg} / \mathrm{L}$. Compared to $\mathrm{Cu}^{2+}$ and $\mathrm{As}^{3+}, \mathrm{Zn}^{2+}$ demonstrated weaker inhibitory effects on urease activity. $\mathrm{Zn}$ ion has been previously reported as a relatively weak inhibitor of urease [30]. This is probably due to its less toxic nature. Treatment of G.max urease with Chromium (III) ions also led to a dose dependent inhibition of the enzyme activity. The inhibition was observed over a concentration range of 0.001-10 mg/L. The assay revealed an inhibition of $8.84 \%$ at $0.001 \mathrm{mg} / \mathrm{L}$ and $78.45 \%$ at $10 \mathrm{mg} / \mathrm{L}$ concentration. $\mathrm{Cr}^{3+}$ showed stronger inhibitory effects than $\mathrm{Zn}^{2+}$ but weaker than $\mathrm{Cu}^{2+}$ and $\mathrm{As}^{3+}$ ions. These trends can be justified either in terms of their respective affinities for urease $-\mathrm{SH}$ groups or their relative toxicities.

Table 3: Urease Inhibition assay for zinc

\begin{tabular}{|l|l|l|}
\hline $\begin{array}{l}\mathbf{Z n}^{2+} \text { Concentration } \\
(\mathbf{m g} / \mathbf{L})\end{array}$ & $\begin{array}{l}\text { Absorbance } \\
(\mathbf{a t} 405 \mathbf{~ n m})\end{array}$ & $\begin{array}{l}\text { Inhibition } \\
(\mathbf{\%})\end{array}$ \\
\hline $0.00($ Control) & $1.652 \pm 0.06$ & 0 \\
0.001 & $1.716 \pm 0.12$ & NI \\
0.01 & $1.681 \pm 0.13$ & NI \\
0.1 & $1.406 \pm 0.07$ & 14.89 \\
1 & $1.311 \pm 0.11$ & 20.64 \\
10 & $0.602 \pm 0.03$ & 63.55 \\
\hline
\end{tabular}

Absorbances are presented as mean \pm SD for three determinations; NI=No inhibition 
Table 4: Urease inhibition assay for chromium

\begin{tabular}{|l|l|l|}
\hline $\begin{array}{l}\mathbf{C r}^{\mathbf{3}} \mathbf{C o n c e n t r a t i o n} \\
(\mathbf{m g} / \mathbf{L})\end{array}$ & $\begin{array}{l}\text { Absorbance } \\
(\mathbf{a t} \mathbf{4 0 5} \mathbf{~ n m})\end{array}$ & $\begin{array}{l}\text { Inhibition } \\
(\mathbf{\%})\end{array}$ \\
\hline $0.00($ Control $)$ & $1.652 \pm 0.03$ & 0 \\
0.001 & $1.506 \pm 0.07$ & 8.84 \\
0.01 & $1.457 \pm 0.10$ & 11.08 \\
0.1 & $1.406 \pm 0.05$ & 14.89 \\
1 & $1.256 \pm 0.11$ & 23.97 \\
10 & $0.356 \pm 0.13$ & 78.45 \\
\hline
\end{tabular}

Absorbances are presented as mean \pm SD for three determinations

Data on the inhibition assay for $\mathrm{Cd}^{2+}$ (Table 5) show that the catalytic activity of Glycine max urease is inhibited in a dose- dependent fashion by $\mathrm{Cd}$ ions within the range of $0.001-10 \mathrm{mg} / \mathrm{L}$ concentration. The inhibition caused by cadmium appear to be less than that observed for $\mathrm{Cu}^{2+}, \mathrm{As}^{3+}$ and $\mathrm{Cr}^{3+}$ but greater than the inhibition by $\mathrm{Zn}^{2+}$. This suggests that perhaps $\mathrm{Cd}^{2+}$ has a lower affinity for urease thiol groups than the three metals $(\mathrm{Cu}$, As and $\mathrm{Cr}$ ). Lead (II) ions showed weak inhibitory effects on G.max urease activity as seen from the results of the inhibition assay presented in Table 6. No clear inhibition of enzyme activity was observed at 0.001 and $0.01 \mathrm{mg} / \mathrm{L} \mathrm{Pb}^{2+}$ concentration. However at $0.1 \mathrm{mg} / \mathrm{L}$, a pronounced decrease in the activity was recorded. Percentage inhibition range of 13.07 - 57.93 was obtained over a concentration range of $0.1-10 \mathrm{mg} / \mathrm{L}$. The inhibition caused by $\mathrm{Pb}$ was much less than observed for the other metals investigated. A Survey of published data confirms the weak inhibitory effects of $\mathrm{Pb}^{2+}$ on urease activity; It has been reported that $\mathrm{Pb}$ (II) ions did not produce a significant decrease in urease activity at concentrations up to $50 \mathrm{mg} \mathrm{L}^{-1}$ [31], whereas Cd (II) and $\mathrm{Zn}$ (II) inactivated urease in the range of $1-30 \mathrm{mg} \mathrm{L}^{-1}$. [32]; Lee and Lee [33] also showed that $\mathrm{Pb}^{2+}$ exhibited weaker inhibition of urease activity compared with $\mathrm{Cu}^{2+}$ and $\mathrm{Cd}^{2+}$.

Table 5: Urease inhibition assay for cadmium

\begin{tabular}{|l|l|l|}
\hline $\begin{array}{l}\mathbf{C d}^{2+} \text { Concentration } \\
(\mathbf{m g} / \mathbf{L})\end{array}$ & $\begin{array}{l}\text { Absorbance at } \\
\mathbf{( 4 0 5} \mathbf{~ n m})\end{array}$ & $\begin{array}{l}\text { Inhibition } \\
\mathbf{( \% )}\end{array}$ \\
\hline $0.00($ Control) & $1.658 \pm 0.06$ & 0 \\
0.001 & $1.475 \pm 0.01$ & 11.03 \\
0.01 & $1.339 \pm 0.10$ & 19.24 \\
0.1 & $1.288 \pm 0.05$ & 22.32 \\
1 & $1.198 \pm 0.01$ & 27.74 \\
10 & $0.421 \pm 0.03$ & 74.61 \\
\hline
\end{tabular}

Absorbances are presented as mean \pm SD for three determinations

Table 6: Urease inhibition assay for Lead

\begin{tabular}{|l|l|l|}
\hline $\begin{array}{l}\mathbf{P b}^{2+} \text { Concentration } \\
(\mathbf{m g} / \mathbf{L})\end{array}$ & $\begin{array}{l}\text { Absorbance } \\
(\mathbf{a t} \text { 405 } \mathbf{~ n m})\end{array}$ & $\begin{array}{l}\text { Inhibition } \\
(\boldsymbol{\%})\end{array}$ \\
\hline $0.00($ Control) & $1.652 \pm 0.06$ & 0 \\
0.001 & $1.648 \pm 0.09$ & 0.24 \\
0.01 & $1.650 \pm 0.12$ & 0.12 \\
0.1 & $1.436 \pm 0.06$ & 13.07 \\
1 & $1.375 \pm 0.10$ & 16.77 \\
100 & $0.695 \pm 0.07$ & 57.93 \\
\hline
\end{tabular}

Absorbances are presented as mean \pm SD for three determinations

\subsection{Inhibition Assay for mixed - metal Solutions}

Co-existence of heavy metals is commonly encountered in the environment as a result of human and natural activities. During inhibition analysis, the presence of other metal ions may elicit antagonistic, additive or synergistic effects. In order to understand the effect of these chemicals in totality, and also ascertain the applicability of the proposed system for sensing of total heavy metal ions, assays were carried to evaluate the inhibition of G.max urease by mixtures of all the investigated heavy metals. The results of the inhibition assays on the mixed- metals (Table 7) also demonstrated dose dependent inhibition of urease activity. However, the measured responses were found to be greater than for the single-metal solutions at all the tested concentrations. The inhibition pattern seemed synergetic but not additive. The effects of a mixture of metal ions on urease activity have been previously shown to be synergetic in such a way that the total urease inhibition can be calculated by addition of the estimated inhibition values for individual cations [34]. Our finding here does not indicate such additive synergism but suggests a potentiating type. Potentiation here refers to the enhancement of one agent by another so that the combined effect is greater than the effect of each one alone. The inhibition pattern demonstrated by the mixed-metal solutions reflects such effects. For the single metal systems, the inhibition obtained at the lowest tested concentration $(0.001 \mathrm{mg} / \mathrm{L})$ ranged from $8.84-24.27 \%$ while for the mixed - metal systems, 37.97\% was obtained. At $10 \mathrm{mg} / \mathrm{L}, 55.41-88.59 \%$ inhibitions were obtained for the 
single-metal solutions and $97.00 \%$ for the multi-metal solutions. These values show that the mixed -metals exhibit a pattern of inhibition enhancement that is not of an additive nature.

Table 7: Urease inhibition assay for mixed metal standards

\begin{tabular}{|l|l|l|}
\hline $\begin{array}{l}\text { Concentration } \\
(\mathbf{m g} / \mathbf{L})\end{array}$ & $\begin{array}{l}\text { Absorbance } \\
\text { (at 405nm) }\end{array}$ & $\begin{array}{l}\text { Inhibition } \\
(\mathbf{\%})\end{array}$ \\
\hline 0.00 (Control) & $1.667 \pm 0.07$ & 0 \\
0.001 & $1.034 \pm 0.13$ & 37.97 \\
0.01 & $0.984 \pm 0.12$ & 40.97 \\
0.1 & $0.917 \pm 0.16$ & 44.99 \\
1 & $0.850 \pm 0.10$ & 49.01 \\
10 & $0.05 \pm 0.03$ & 97 \\
\hline
\end{tabular}

Absorbances are presented as mean \pm SD for three determinations

\subsection{Inhibition Plots}

In enzyme inhibition assays, a plot of \% inhibition against concentration of inhibitor is usually employed as calibration graph for determination of the inhibitor concentration. The features of the inhibition calibration plots for the investigated metal solutions are presented in Table 8. The inhibition plots for $\mathrm{Cu}^{2+}$ and $\mathrm{As}^{3+}$ showed linear relationships within the concentration range of $0.01-10 \mathrm{mg} / \mathrm{L}$. However, the inhibition pattern of arsenic (III) ion was quite different from that exhibited by Copper. Within the same concentration range of $0.001-10 \mathrm{mg} / \mathrm{L}, \mathrm{Cu}$ showed a wider percentage inhibition range; $11.83-87.42$ against $24.27-88.59$ obtained for arsenic. These differences are seen reflected in their respective inhibition graphs; Arsenic inhibition plot revealed a smaller slope values (4.575)) than copper with 6.6997. The slope is a measure of the sensitivity of a calibration curve; the steeper the slope, the more sensitive the procedure i.e., the stronger the response on $y$-axis to a concentration change. The lower slope values obtained for arsenic plot indicate lesser steepness which suggests that the system is less sensitive for detection of arsenic than for copper. High sensitivity in inhibition assays is usually due to high inhibition efficiency of the analyte [35]. The inhibition pattern for zinc was linear in the concentration range of $0.1-1 \mathrm{mg} / \mathrm{L}$ with higher slope values than for $\mathrm{As}^{3+}$ but lower than obtained for $\mathrm{Cu}^{2+}$. This suggests that the system's sensitivity towards zinc is higher than that of $\mathrm{As}^{3+}$ but lower than for $\mathrm{Cu}^{2+}$. The inhibition plot for $\mathrm{Cr}^{3+}$ exhibited a linear relationship within $0.01-10 \mathrm{mg} / \mathrm{L}$ concentration with a correlation of $99.73 \%$. The sensitivity of the inhibition assay for $\mathrm{Cr}^{3+}$ can be inferred from the slopes of the calibration lines which was obtained as 6.4241.This value suggest relatively good sensitivity towards $\mathrm{Cr}$; comparable to that of Copper but better than for Arsenic and Zinc. Linearity was established between $\mathrm{Cd}^{2+}$ ion concentration and \% inhibition of urease activity within $0.01-10 \mathrm{mg} / \mathrm{L}$ concentration. The slope here also suggests relatively good calibration sensitivity for Cd detection. The linear range for estimation of $\mathrm{Pb}^{2+}$ was established between $0.1-10 \mathrm{mg} / \mathrm{L}$ concentration with an $\mathrm{R}^{2}$ value of $99.99 \%$. It seems that better correlation of the linear model is achieved when the range of inhibition is smaller. Among the investigated metals, $\mathrm{Zn}^{2+}$ and $\mathrm{Pb}^{2+}$ which showed smaller inhibition range (within $0.1-10 \mathrm{mg} / \mathrm{L}$ ), consequently gave higher correlation values. The inhibitory responses for the multi- metal solutions were linear in the concentration range of $0.001-10 \mathrm{mg} / \mathrm{L}$. The linear range obtained here is wider than for all the single metal systems. This is a reflection of the intensified inhibitory effects of the mixed metals.

Table 9: Features of inhibition calibration plots for investigated heavy metals

\begin{tabular}{|l|l|l|l|}
\hline Heavy metals & Regression equation & Linear range & $\left.\mathbf{R}^{\mathbf{2}} \mathbf{\%}\right)$ \\
\hline $\mathrm{Cu}$ & $\mathrm{Y}=6.6997 \mathrm{x}+20.6166$ & $0.01-10 \mathrm{mg} / \mathrm{L}$ & 99.68 \\
$\mathrm{As}$ & $\mathrm{Y}=4.5975 \mathrm{x}+42.7129$ & $0.01-10 \mathrm{mg} / \mathrm{L}$ & 99.79 \\
$\mathrm{Zn}$ & $\mathrm{Y}=4.8554 \mathrm{x}+15.0617$ & $0.1-10 \mathrm{mg} / \mathrm{L}$ & 99.93 \\
$\mathrm{Cr}$ & $\mathrm{Y}=6.4641 \mathrm{x}+14.1437$ & $0.01-10 \mathrm{mg} / \mathrm{L}$ & 99.28 \\
$\mathrm{Cd}$ & $\mathrm{Y}=5.3677 \mathrm{x}+21.0687$ & $0.01-10 \mathrm{mg} / \mathrm{L}$ & 99.72 \\
$\mathrm{~Pb}$ & $\mathrm{Y}=4.5483 \mathrm{x}+12.4278$ & $0.1-10 \mathrm{mg} / \mathrm{L}$ & 99.99 \\
Mixed-metal & $\mathrm{Y}=5.5569 \mathrm{x}+41.6395$ & $0.001-10 \mathrm{mg} / \mathrm{L}$ & 98.94 \\
\hline
\end{tabular}

\subsection{Half Maximal Inhibitory Concentration (IC50) Values}

The heavy metals investigated in this study showed varying inhibitory strengths on urease activity. This can be seen from their respective IC 50 values (Table 8) derived from least squares linear regression of the \% inhibition plots. IC 50 (inhibitory concentration 50) is the concentration of an inhibitor at which $50 \%$ inhibition occurs. It is commonly used as a measure of the inhibitory effectiveness of a substance; the lower the IC 50 value, the stronger the inhibitory effect. Our data showed the following ranking of inhibition by the metals: $\mathrm{As}(\mathrm{III})>\mathrm{Cu}(\mathrm{II})>\mathrm{Cr}(\mathrm{III})>\mathrm{Cd}(\mathrm{II})>\mathrm{Zn}(\mathrm{II})>\mathrm{Pb}(\mathrm{II})$. A survey of previously reported studies showed some disagreements on the inhibitory effects of heavy metals on urease activity; The activity of urease has been shown to be inhibited by heavy metals in the order; $\mathrm{Cd}^{2+}>\mathrm{Ni}^{2+}>\mathrm{Cu}^{2+}>\mathrm{Zn}^{2+}>\mathrm{Co}^{2+}>\mathrm{Fe}^{3+}>\mathrm{Pb}^{2+}[36]$, $\mathrm{Cr}(\mathrm{VI})>\mathrm{Ni}(\mathrm{II})>\mathrm{Cu}(\mathrm{II})>\mathrm{Cd}(\mathrm{II})>\mathrm{Zn}(\mathrm{II})>\mathrm{Pb}$ (II) [37] and $\mathrm{Hg}^{2+}>\mathrm{Cu}^{2+}>\mathrm{Zn}^{2+}>\mathrm{Cd}^{2+}>\mathrm{Ni}^{2+}>\mathrm{Pb}^{2+}>\mathrm{Co}^{2+}>\mathrm{Fe}^{3+}>\mathrm{As}^{3+}$ [30]. The inhibition orders have also been previously reported as $\mathrm{Hg}^{2+}>\mathrm{Ag}^{+}>\mathrm{Cu}^{2+}>\mathrm{Ni}^{2+}>\mathrm{Cd}^{2+}>\mathrm{Zn}^{2+}>\mathrm{Co}^{2+}$ 
$>\mathrm{Fe}^{2+}>\mathrm{Pb}^{2+}>\mathrm{Mn}^{2+}[38]$ and $\mathrm{Cr}>\mathrm{Cd}>\mathrm{Zn}>\mathrm{Mn}>\mathrm{Pb}$ [39]. The reasons for the disparities in the reported data could be due to the nature of the ureases used in the investigations. Ureases from different sources are known to have different characteristics and kinetic properties, this factor may be responsible for the differences in inhibitory strengths reported by various studies.

Table 8: Half Maximal Inhibitory Concentration (IC50) Values of the investigated metals

\begin{tabular}{|l|l|l|l|l|l|l|}
\hline Heavy metals & $\mathrm{As}^{3+}$ & $\mathrm{Cu}^{2+}$ & $\mathrm{Cd}^{2+}$ & $\mathrm{Cr}^{2+}$ & $\mathrm{Zn}^{2+}$ & $\mathrm{Pb}^{2+}$ \\
\hline IC 50 $(\mathbf{m g} / \mathbf{L})$ & 1.584 & 4.386 & 5.390 & 5.547 & 7.197 & 8.260 \\
\hline
\end{tabular}

\subsection{Application of Urease Inhibition Assay to synthetic water samples}

An attempt has been made at estimating the heavy metal concentration of some synthetic water samples by means of the urease inhibition assay. The analysis is aimed at evaluating the performance of the assay by comparing with a standard method (atomic absorption spectroscopy). 10 synthetic samples for each metal were prepared by adding unknown quantities of the metal solutions to distilled water. Solutions of mixed metals were also prepared in the same manner. Measurements of urease inhibition by the solutions were carried out and the concentrations of the samples were estimated from their respective inhibition plots. The data from the inhibition assay is summarized in Table 9, the results of the AAS analysis for the multi-metal samples are presented in Table 10 while a comparative evaluation of the results obtained via the two methods is presented in Table 11.

Table 9: Summary of data on urease inhibition assay for heavy metals in synthetic water samples

\begin{tabular}{|l|c|c|c|c|}
\hline Heavy metals & Sample size & $\begin{array}{c}\text { Absorbance } \\
\text { (range) }\end{array}$ & $\begin{array}{c}\text { \% inhibition } \\
\text { (range) }\end{array}$ & $\begin{array}{c}\text { Concentration range } \\
\text { obtained (mg/L) }\end{array}$ \\
\hline Copper(II) & 10 & $1.034-1.352$ & $15.82-35.61$ & $0.278-2.238$ \\
Arsenic(III) & 10 & $0.805-0.858$ & $50.05-53.14$ & $1.596-2.268$ \\
Cadmium(II) & 10 & $1.021-1.297$ & $21.77-38.41$ & $0.131-3.231$ \\
Zinc(II) & 10 & $0.486-1.268$ & $23.24-70.58$ & $1.684-11.434$ \\
Chromium (III) & 10 & $1.213-1.505$ & $8.90-26.57$ & $0.106-1.804$ \\
Lead(II) & 10 & $0.163-1.626$ & $3.15-90.13$ & $1.007-17.084$ \\
Mixed metals & 10 & $0.561-0.800$ & $52.02-66.35$ & $(1.886-4.447)^{*}$ \\
\hline
\end{tabular}

*Concentrations for samples diluted to a factor of $10^{-1}$

The analysis of $\mathrm{Cu}$ synthetic samples via the inhibition assay revealed a concentration range of $0.278-$ $2.238 \mathrm{mg} / \mathrm{L}$ while AAS analysis gave $0.006-2.271 \mathrm{mg} / \mathrm{L}$. Statistical comparison of the results by t-test analysis showed good agreement between the two methods; $90 \%$ of the results evaluated showed no significant difference from each other at $95 \%$ confidence level. Determination of Arsenic by the two methods also gave comparable results; $1.596-2.268 \mathrm{mg} / \mathrm{L}$ and $1.553-2.292 \mathrm{mg} / \mathrm{L}$ from the inhibition assay and AAS methods respectively. Only $10 \%$ significant difference was observed among the results. The concentration of cadmium obtained from AAS analysis was in the range of $0.140-3.216 \mathrm{mg} / \mathrm{L}$ against $0.131-3.231 \mathrm{mg} / \mathrm{L}$ obtained from the inhibition method. T-test evaluation showed that only one out of the 10 samples investigated differed significantly at $95 \%$ confidence level.

Table 10: Determination of heavy metals in mixed-metal synthetic samples by Atomic Absorption spectroscopy

(AAS)

\begin{tabular}{|l|c|c|c|c|c|c|c|}
\hline \multicolumn{7}{|c|}{ Obtained concentration $\mathbf{( m g} / \mathbf{L})$} \\
\hline Sample & $\mathbf{C u}^{\mathbf{2 +}}$ & $\mathbf{A s}^{\mathbf{3 +}}$ & $\mathbf{C d}^{\mathbf{2 +}}$ & $\mathbf{C r}^{\mathbf{3 +}}$ & $\mathbf{Z n}^{\mathbf{2 +}}$ & $\mathbf{P b}^{\mathbf{2 +}}$ & $\mathbf{T o t a l}$ \\
\hline MM-A & $4.613 \pm 0.14$ & $0.137 \pm 0.05$ & $4.889 \pm 0.13$ & $0.454 \pm 0.02$ & $19.490 \pm 1.2$ & $1.672 \pm 0.11$ & $\mathbf{3 1 . 1 8 5} \pm \mathbf{1 . 6 5}$ \\
MM-B & $2.280 \pm 0.12$ & $0.134 \pm 0.07$ & $7.405 \pm 0.22$ & $0.643 \pm 0.10$ & $9.469 \pm 0.56$ & $0.945 \pm 0.09$ & $\mathbf{2 0 . 8 7 6} \pm \mathbf{1 . 1 6}$ \\
MM-C & $4.899 \pm 0.25$ & $0.157 \pm 0.04$ & $16.64 \pm 1.12$ & $0.625 \pm 0.08$ & $17.138 \pm 1.05$ & $3.419 \pm 0.20$ & $\mathbf{4 2 . 8 7 8} \pm \mathbf{2 . 7 4}$ \\
MM-D & $2.167 \pm 0.15$ & $0.121 \pm 0.02$ & $8.546 \pm 0.42$ & $0.365 \pm 0.03$ & $18.086 \pm 0.62$ & $2.773 \pm 0.23$ & $\mathbf{3 2 . 0 5 8} \pm \mathbf{1 . 4 7}$ \\
MM-E & $1.113 \pm 0.07$ & $0.180 \pm 0.01$ & $24.037 \pm 0.72$ & $0.903 \pm 0.06$ & $16.410 \pm 0.46$ & $2.489 \pm 0.05$ & $\mathbf{4 5 . 1 3 2} \pm \mathbf{1 . 3 7}$ \\
MM-F & $5.659 \pm 0.05$ & ND & $8.806 \pm 0.32$ & $0.471 \pm 0.00$ & $17.398 \pm 0.24$ & $3.016 \pm 0.18$ & $\mathbf{3 5 . 3 5 3} \pm \mathbf{0 . 7 9}$ \\
MM-G & $5.679 \pm 0.10$ & ND & $13.618 \pm 0.21$ & $0.221 \pm 0.01$ & $12.091 \pm 0.13$ & $4.237 \pm 0.08$ & $\mathbf{3 5 . 5 4 6} \pm \mathbf{0 . 5 2}$ \\
MM-H & $7.732 \pm 0.13$ & ND & $16.091 \pm 0.51$ & $0.496 \pm 0.02$ & $18.854 \pm 0.87$ & $4.655 \pm 0.03$ & $\mathbf{4 7 . 8 2 7} \pm \mathbf{1 . 5 6}$ \\
MM-I & $4.313 \pm 0.07$ & $0.008 \pm 0.00$ & $20.018 \pm 0.62$ & $0.938 \pm 0.12$ & $14.338 \pm 0.14$ & $2.003 \pm 0.07$ & $\mathbf{4 1 . 6 1 8 \pm 1 . 0 2}$ \\
MM-J & $9.383 \pm 0.36$ & ND & $7.165 \pm 0.16$ & $0.123 \pm 0.03$ & $18.062 \pm 0.88$ & $2.800 \pm 0.12$ & $\mathbf{3 7 . 5 3 3} \pm \mathbf{0 . 5 5}$ \\
\hline
\end{tabular}

Results are presented as Mean \pm SD for three determinations

The data on the estimation of $\mathrm{Cr}$ (III) by the inhibition assay method gave $0.118-1.910 \mathrm{mg} / \mathrm{L}$ while the AAS method gave $0.108-1.770 \mathrm{mg} / \mathrm{L}$ concentration. Two out of the 10 investigated samples could not be quantified by the two methods implying that the concentrations were below the detection limits of both procedures. Although the inhibition assays established some levels of inhibition for the two samples (Cr-D and $\mathrm{Cr}-\mathrm{F}$ ), they could not be quantified as the obtained inhibition values were not within the linear range of the $\mathrm{Cr}$ calibration plot. T-test examination revealed that the concentrations of two samples differed significantly among the two methods. AAS analysis for $\mathrm{Zn}$ gave a concentration range of $1.788-11.625 \mathrm{mg} / \mathrm{L}$ and the inhibition assay gave $1.684-11.434 \mathrm{mg} / \mathrm{L}$. The results from the two techniques were not significantly different for $80 \%$ of the analysed samples at $95 \%$ confidence level. $\mathrm{Pb}$ concentration in the range of $0.007-17.43 \mathrm{mg} / \mathrm{L}$ was 
obtained via AAS while 1.007 - $17.084 \mathrm{mg} / \mathrm{L}$ was obtained via the urease inhibition assay. Here, the inhibition method differed significantly from AAS in $40 \%$ of the analysed samples. The reason for this high discrepancy could be due to the weak inhibitory effects of $\mathrm{Pb}^{2+}$ on urease activity which has been attributed to its poor affinity for the enzyme. This may have resulted in less sensitivity of the inhibition system towards $\mathrm{Pb}^{2+}$.

For the analysis of the multi-metal synthetic samples, AAS was first used to estimate the concentrations of the individual metals then the sum of the measured concentrations was taken as the total concentration (Table 10). The inhibition assays were used to estimate the concentration of the samples (as total heavy metals present) based on the respective inhibition values. For the inhibition assays, all the samples were diluted to a factor $10^{-1}$ before measurable responses could be obtained. Comparisons of the total concentrations estimated via the two methods revealed about $70 \%$ significant differences. It appears the inhibition assay does not give full quantitative information with respect to multiple metals in solution; it seems to give a sum value of the heavy metal related toxicity of the samples. The results obtained via the assays were all lower than those obtained through AAS analysis thus giving further credence to our earlier observation that the inhibitory effect of mixed metals on urease activity is not additively synergetic.

Table 11: Comparative evaluation of two methods (urease Inhibition Assay and Atomic Absorption Spectroscopy) used to determine Heavy Metal Contents of synthetic water Samples

\begin{tabular}{|c|c|c|c|c|}
\hline Heavy metals & Samples & $\begin{array}{c}\text { Atomic absorption spectroscopy } \\
\text { concentration }(\mathrm{mg} / \mathrm{L})\end{array}$ & $\begin{array}{l}\text { Urease inhibition assay } \\
\text { concentration }(\mathrm{mg} / \mathrm{L})\end{array}$ & T-test values \\
\hline Copper & $\begin{array}{l}\mathrm{Cu}-\mathrm{A} \\
\mathrm{Cu}-\mathrm{B} \\
\mathrm{Cu}-\mathrm{C} \\
\mathrm{Cu}-\mathrm{D} \\
\mathrm{Cu}-\mathrm{E} \\
\mathrm{Cu}-\mathrm{F} \\
\mathrm{Cu}-\mathrm{G} \\
\mathrm{Cu}-\mathrm{H} \\
\mathrm{Cu}-\mathrm{I} \\
\mathrm{Cu}-\mathrm{J}\end{array}$ & $\begin{array}{l}0.295 \pm 0.05 \\
0.694 \pm 0.12 \\
1.119 \pm 0.02 \\
1.063 \pm 0.03 \\
2.119 \pm 0.04 \\
2.271 \pm 0.01 \\
0.994 \pm 0.03 \\
2.244 \pm 0.15 \\
0.988 \pm 0.06 \\
0.006 \pm 0.00\end{array}$ & $\begin{array}{c}0.278 \pm 0.04 \\
0.667 \pm 0.02 \\
1.114 \pm 0.13 \\
1.096 \pm 0.09 \\
1.989 \pm 0.07 \\
2.183 \pm 0.10 \\
0.975 \pm 0.03 \\
2.238 \pm 0.06 \\
0.984 \pm 0.03 \\
\text { ND }\end{array}$ & $\begin{array}{l}0.460 \\
0.384 \\
0.066 \\
0.603 \\
2.792^{*} \\
1.517 \\
0.776 \\
0.064 \\
0.103 \\
\text { NA }\end{array}$ \\
\hline Arsenic & $\begin{array}{l}\text { As-A } \\
\text { As-B } \\
\text { As-C } \\
\text { As-D } \\
\text { As-E } \\
\text { As-F } \\
\text { As-G } \\
\text { As-H } \\
\text { As-I } \\
\text { As-J }\end{array}$ & $\begin{array}{l}1.734 \pm 0.04 \\
1.558 \pm 0.02 \\
1.645 \pm 0.01 \\
2.292 \pm 0.06 \\
2.223 \pm 0.16 \\
2.255 \pm 0.08 \\
2.268 \pm 0.03 \\
1.897 \pm 0.05 \\
1.861 \pm 0.02 \\
1.862 \pm 0.12 \\
\end{array}$ & $\begin{array}{l}1.711 \pm 0.12 \\
1.596 \pm 0.04 \\
1.622 \pm 0.05 \\
2.268 \pm 0.11 \\
2.205 \pm 0.14 \\
2.244 \pm 0.06 \\
2.166 \pm 0.03 \\
1.877 \pm 0.02 \\
1.850 \pm 0.06 \\
1.863 \pm 0.09 \\
\end{array}$ & $\begin{array}{l}0.315 \\
1.472 \\
0.781 \\
0.332 \\
0.146 \\
0.191 \\
4.164^{*} \\
0.643 \\
0.301 \\
0.012 \\
\end{array}$ \\
\hline Cadmium & $\begin{array}{l}\text { Cd-A } \\
\text { Cd-B } \\
\text { Cd-C } \\
\text { Cd-D } \\
\text { Cd-E } \\
\text { Cd-F } \\
\text { Cd-G } \\
\text { Cd-H } \\
\text { Cd-I } \\
\text { Cd-J }\end{array}$ & $\begin{array}{c}1.156 \pm 0.09 \\
1.00 \pm 0.01 \\
2.582 \pm 0.06 \\
1.850 \pm 0.04 \\
3.216 \pm 0.03 \\
2.242 \pm 0.09 \\
1.508 \pm 0.07 \\
0.230 \pm 0.03 \\
0.247 \pm 0.01 \\
0.140 \pm 0.00 \\
\end{array}$ & $\begin{array}{l}1.131 \pm 0.03 \\
0.975 \pm 0.05 \\
2.413 \pm 0.05 \\
1.895 \pm 0.10 \\
3.231 \pm 0.11 \\
2.255 \pm 0.06 \\
1.480 \pm 0.02 \\
0.222 \pm 0.02 \\
0.244 \pm 0.03 \\
0.131 \pm 0.07 \\
\end{array}$ & $\begin{array}{l}0.456 \\
0.849 \\
3.748^{*} \\
0.189 \\
0.228 \\
0.208 \\
0.666 \\
0.348 \\
0.164 \\
0.221 \\
\end{array}$ \\
\hline Chromium & $\begin{array}{l}\mathrm{Cr}-\mathrm{A} \\
\mathrm{Cr}-\mathrm{B} \\
\mathrm{Cr}-\mathrm{C} \\
\mathrm{Cr}-\mathrm{D} \\
\mathrm{Cr}-\mathrm{E} \\
\mathrm{Cr}-\mathrm{F} \\
\mathrm{Cr}-\mathrm{G} \\
\mathrm{Cr}-\mathrm{H} \\
\mathrm{Cr}-\mathrm{I} \\
\mathrm{Cr}-\mathrm{J} \\
\end{array}$ & $\begin{array}{c}1.770 \pm 0.03 \\
0.198 \pm 0.02 \\
0.249 \pm 0.01 \\
\text { ND } \\
0.108 \pm 0.07 \\
\text { ND } \\
1.837 \pm 0.05 \\
1.972 \pm 0.04 \\
0.766 \pm 0.06 \\
0.194 \pm 0.04 \\
\end{array}$ & $\begin{array}{c}1.735 \pm 0.04 \\
0.180 \pm 0.09 \\
0.219 \pm 0.06 \\
\text { ND } \\
0.106 \pm 0.11 \\
\text { ND } \\
1.800 \pm 0.03 \\
1.775 \pm 0.11 \\
0.621 \pm 0.04 \\
0.125 \pm 0.05 \\
\end{array}$ & $\begin{array}{l}1.212 \\
0.338 \\
0.854 \\
\text { NA } \\
1.099 \\
\text { NA } \\
1.099 \\
2.915^{*} \\
3.723^{*} \\
1.867 \\
\end{array}$ \\
\hline Zinc & $\begin{array}{l}\mathrm{Zn}-\mathrm{A} \\
\mathrm{Zn}-\mathrm{B} \\
\mathrm{Zn}-\mathrm{C} \\
\mathrm{Zn}-\mathrm{D} \\
\mathrm{Zn}-\mathrm{E} \\
\mathrm{Zn}-\mathrm{F} \\
\mathrm{Zn}-\mathrm{G} \\
\mathrm{Zn}-\mathrm{H} \\
\mathrm{Zn}-\mathrm{I} \\
\mathrm{Zn}-\mathrm{J} \\
\end{array}$ & $\begin{array}{c}1.788 \pm 0.08 \\
4.631 \pm 0.04 \\
1.957 \pm 0.02 \\
5.273 \pm 0.09 \\
1.800 \pm 0.05 \\
11.625 \pm 0.13 \\
10.395 \pm 0.10 \\
1.898 \pm 0.06 \\
3.863 \pm 0.03 \\
6.685 \pm 0.07 \\
\end{array}$ & $\begin{array}{c}1.684 \pm 0.11 \\
4.352 \pm 0.12 \\
1.897 \pm 0.05 \\
5.163 \pm 0.15 \\
1.773 \pm 0.10 \\
11.434 \pm 0.22 \\
10.312 \pm 0.09 \\
1.822 \pm 0.08 \\
3.678 \pm 0.06 \\
6.498 \pm 0.13 \\
\end{array}$ & $\begin{array}{l}1.32 \\
3.82^{*} \\
1.93 \\
1.09 \\
0.42 \\
1.29 \\
1.07 \\
1.32 \\
4.78^{*} \\
2.19 \\
\end{array}$ \\
\hline
\end{tabular}




\begin{tabular}{|c|c|c|c|c|}
\hline Heavy metals & Samples & $\begin{array}{c}\text { Atomic absorption spectroscopy } \\
\text { concentration }(\mathrm{mg} / \mathrm{L})\end{array}$ & $\begin{array}{l}\text { Urease inhibition assay } \\
\text { concentration }(\mathrm{mg} / \mathrm{L})\end{array}$ & T-test values \\
\hline Lead & $\begin{array}{l}\mathrm{Pb}-\mathrm{A} \\
\mathrm{Pb}-\mathrm{B} \\
\mathrm{Pb}-\mathrm{C} \\
\mathrm{Pb}-\mathrm{D} \\
\mathrm{Pb}-\mathrm{E} \\
\mathrm{Pb}-\mathrm{F} \\
\mathrm{Pb}-\mathrm{G} \\
\mathrm{Pb}-\mathrm{H} \\
\mathrm{Pb}-\mathrm{I} \\
\mathrm{Pb}-\mathrm{J}\end{array}$ & $\begin{array}{c}17.43 \pm 0.05 \\
2.68 \pm 0.01 \\
1.107 \pm 0.02 \\
\mathrm{ND} \\
1.56 \pm 0.04 \\
\mathrm{ND} \\
1.39 \pm 0.06 \\
0.007 \pm 0.00 \\
\mathrm{ND} \\
2.73 \pm 0.01 \\
\end{array}$ & $\begin{array}{c}17.084 \pm 0.11 \\
2.445 \pm 0.17 \\
1.007 \pm 0.03 \\
\mathrm{ND} \\
1.513 \pm 0.05 \\
\mathrm{ND} \\
1.362 \pm 0.15 \\
\mathrm{ND} \\
\mathrm{ND} \\
2.617 \pm 0.03 \\
\end{array}$ & $\begin{array}{l}4.96^{*} \\
2.39^{*} \\
4.80^{*} \\
\text { NA } \\
1.271 \\
\text { NA } \\
0.3 \\
\text { NA } \\
\text { NA } \\
4.61^{*}\end{array}$ \\
\hline Mixed-metals & $\begin{array}{l}\text { MM-A } \\
\text { MM-B } \\
\text { MM-C } \\
\text { MM-D } \\
\text { MM-E } \\
\text { MM-F } \\
\text { MM-G } \\
\text { MM-H } \\
\text { MM-I } \\
\text { MM-J }\end{array}$ & $\begin{array}{l}31.185 \pm 1.65 \\
20.876 \pm 1.16 \\
42.878 \pm 2.74 \\
32.058 \pm 1.47 \\
45.132 \pm 1.37 \\
35.353 \pm 0.79 \\
35.546 \pm 0.52 \\
47.827 \pm 1.56 \\
41.618 \pm 1.02 \\
37.533 \pm 0.55 \\
\end{array}$ & $\begin{array}{l}25.897 \pm 1.35 \\
18.662 \pm 0.83 \\
40.473 \pm 1.94 \\
27.084 \pm 1.16 \\
40.257 \pm 2.15 \\
31.727 \pm 0.93 \\
28.902 \pm 0.85 \\
44.468 \pm 2.60 \\
37.558 \pm 1.21 \\
33.437 \pm 1.30\end{array}$ & $\begin{array}{l}3.48^{*} \\
2.69 \\
1.24 \\
4.60^{*} \\
3.31^{*} \\
5.15^{*} \\
11.6^{*} \\
1.92 \\
4.44^{*} \\
5.03^{*}\end{array}$ \\
\hline
\end{tabular}

\section{Conclusion}

Inhibition studies are the first step towards developing an enzyme-inhibition based system for detection of heavy metals. Here we have carried out inhibition assays for six heavy metals using urease extracted from Glycine max seeds. All the investigated heavy metals exhibited linearly related dose-dependent inhibition of urease activity within varying concentrations. This factor demonstrates the feasibility of using the extracted urease for quantitative determination the metals. Application of the inhibition assay to single-metal synthetic samples gave satisfactory results when compared with atomic absorption spectroscopy (AAS) analysis. However, for the analysis of multi-metal samples, wide discrepancies were observed. This can be attributed to the pattern of inhibition by the mixed - metals which showed non-additive behaviour. Being inhibition based, the method under consideration cannot differentiate between inhibitors of the same class therefore it cannot discern which metals are present in a particular sample; it can only give a sum parameter of the overall heavy metal-associated toxicity of a sample. It would be useful as a screening tool to assess heavy metal contamination in water samples.

\section{References}

[1] N. Gan, X.Yang, D. Xie, Y. Wu and W. Wen, A disposable organophosphorus pesticides enzyme biosensor based on magnetic composite nano-particles modified screen printed carbon electrode, Sensors, 10, 2010, 625-638.

[2] Y. Braham, H. Barhoumi and A. Maaref, Urease capacitive biosensors using functionalized magnetic nanoparticles for atrazine pesticide detection in environmental samples, Anal. Methods, 5, 2013, 4898.

[3] K. Loh, Y. H. Lee, A. Musa, A. Salmah and I. Zamri, Use of $\mathrm{Fe}_{3} \mathrm{O}_{4}$ nanoparticles for enhancement of biosensor response to the herbicide 2,4-dichlorophenoxyacetic acid, Sensors, 8, 2008, 5775-5791.

[4] S.R Budnikov, O.O Soldatkin , A.L Kukla, I.I Khomenko, S.V Dzyadevych and O.P Soldatkin , Investigation and optimization of reactivation of urease biosensor for heavy metals inhibition analysis, Biotechnologia acta, 8, (6), 2015, 16-21.

[5] S.A Ahmad, M.I.E. Halmi, M.H Wasoh, W.L.W. Johari, M.Y Shukor, and M.A Syed, The development of a specific inhibitive enzyme assay for the heavy metal lead, JEBAT, 1(1), 2013, 9-13.

[6] G.A Evdokimova . Microbiological activity of soils contaminated by heavy metals. Pochvovedenie, 6, $1982,125-132$.

[7] A.M Barrios and S.J Lippard, Interaction of urea with a hydroxide bridged dinuclear nickel center: an alternative model for the mechanism of urease. J. Am. Chem.Soc., 122, 2000, 9172-9177.

[8] M. Khan, M.M Javed, S. Zahoor and U. Ikram, Kinetics And Thermodynamic Study of Urease Extracted From Soybeans. Biologia Pakistan 59 (1), 2013, 7-14.

[9] S. Banerjee and A. Aggarwal, Isolation, partial purification, characterization and inhibition of urease (E.C. 3.5.1.5) enzyme from the Cajanus cajan seeds. Asian Journal of Bio. 7 (2), 2012, 203-209.

[10] A. Goldraij, L.J Beamer and J.C Polacco, Interallelic complementation at the ubiquitous urease coding locus of soybean. J. Am. Soc. Plant.Biol., 4, 2003, 1801-1810.

[11] L.E Meyer-Bothling and J.C Polacco, Mutational analysis of the embryo-specific urease locus of soybean, Mol Gen. Genet., 209, $1987,439-444$.

[12] R.S Torisky, J.D Griffin, R.L Yenofsky and J.C Polacco, A single gene (Eu4) encodes the tissue-ubiquitous urease of soybean, Mol Gen Genet., 242, 1994, 404-414.

[13] R.P. Hausinger, Urease, in Biochemistry of Nickel (New york, Plenum Press, 1993) 23-57.

[14] P. Bhattacharyya, S. Tripathy, K. Kim, and S. Kim, Arsenic fractions and enzyme activities in arsenic-contaminated soils by groundwater irrigation in West Bengal. Ecotox Environ Safe 8, 15, 2007.

[15] R. Sharma, Y.S Rajput, S. Kaur, and S.K Tomar, A method for estimation of urea using ammonia electrode and its applicability to milk samples. J. Dairy Res., 75, 2008, 466-470.

[16] F.J Sangari, A. Seoane, M.C Rodriguez, J. Aguero and J.M Garcia- Lobo, Characterization of the urease operon of Brucella abortus and assessment of its role in virulence of the bacterium. Infect. Immun 75(2), 2007, 774-780. 
[17] H. Kaur, S. Kumar, and N. Verma, Enzyme-based Colorimetric and Potentiometric Biosensor for Detecting Pb (II) Ions in Milk, Brazilian archives of Biology and technology 57 (4), 2014, 613-619

[18] L.M Costa Silva, A.C.S Pinto, A.C Andrea, M. Salgado, and M.A.Z Coelho, Development of Potentiometric Urea Biosensor Based on Canavalia ensiformis Urease in Biosensors-Emerging Materials and Applications, retrieved from: http://www.intechopen.com/books, 2011.

[19] N. Du, M.Chen, Z. Liu, L. Sheng, H. Xu and S. Chen, Kinetics and mechanism of jack bean urease inhibition by Hg ${ }^{2+}$. Chem Cent J. 6, 1542012 .

[20] M.R.M Hussin, (2015). Urease Kinetics and the Effect of Nickel and two Nitrogen Sources on Urease Activity in Selected Legume Plants. Doctoral Thesis and Dissertation, University of Khartoum 2015, Retrieved from http://khartoumspace.uofk.edu 15/09/2016

[21] B.E Dunn, G.P Campbell, G.I Perez-Perez and M.J Blaser, Purification and characterization of urease from Helicobacter pylori. J. Biol. Chem. 265, 1990, 9464-9469.

[22] ATSDR - Agency for Toxic Substances and Disease Registry, Detailed Data Table for the 2011 Priority List of Hazardous Substances. Retrieved from: www.atsdr.cdc.gov/SPL, 24/11/2016

[23] B. Krajewska, Mono- $(\mathrm{Ag}, \mathrm{Hg})$ and di- $(\mathrm{Cu}, \mathrm{Hg})$ valent metal ions effects on the activity of jack bean urease, Probing the modes of metal binding to the enzyme. J. Enzyme Inhib Med Chem, 7, 2008,535-542

[24] P. Pal, D. Bhattacharyay, A. Mukhopadhyay and P. Sarkar, The detection of mercury, cadium, and arsenic by the deactivation of urease on rhodinized carbon. Environ. Eng. Sci. 26, 2009, 25-32

[25] R.P Dick, Soil enzyme activities as integrative indicators of soil health, In VVSR(eds) Biological indicators of soil health, (New york, CAB international 1997) $121-156$.

[26] A. Karaca, S.C Cetin, O.C Turgay and R. Kizilkaya, Effect of heavy metals on soil enzyme activities, in Sherameti and A. Varma (eds.), Soil Heavy Metals, (Springer-Verlag Berlin Heidelberg 2010) 237-262 I.

[27] D.A Dalton, H.J Evans and F.J Hanus, Stimulation by nickel of soil microbial urea activity and urease and hydrogenase activity in soybeans grown in a low-nickel soil. Plant Soil, 88, 1985, 245-58

[28] A. Siedlecka and Z. Krupa, Functions of enzymes in heavy metal treated plants, in: Prasad M N V, Kazimierz S, (eds.), Physiology and Biochemistry of Metal Toxicity and Tolerance in Plants (Kluwer, The Netherlands 2002) 314-3177.

[29] S. Nanda and J. Abraham, Remediation of heavy metal contaminated soil. African Journal of Biotechnology 12(21), 2013, 30993109.

[30] W. Zaborska, B. Krajewska, and Z. Olech, Heavy metal ions inhibition of jack bean urease: Potential for rapid contaminant probing. J. Enzyme Inhib. Med. Chem., 19 (1), 2004, 65-69.

[31] B.B Rodriguez, J.A Bolbot and I.E Tothill, Development of urease and glutamic dehydrogenase amperometric assay for heavy metals screening in polluted samples Biosensors and Bioelectronics 19, 2004, 1157-1167.

[32] R. Ilangovan, D. Daniel, A. Krastanov, C. Zachariah, and R. Elizabeth, "Enzyme based biosensor for heavy metal ions determination," Biotechnology and Biotechnological Equipment, 20(1), 2006, 184-189.

[33] S.Lee and W. Lee, Determination of heavy metal ions using conductometric biosensor based on sol-gel-immobilized urease. Bull. Korean Chem. Soc. 23 (8), 2002, 1169-1172

[34] T.K.V Krawczyk, M. Moszczyńska and M.Trojanowicz, Inhibitive determination of mercury and other metals by a potentiometric urea biosensor Biosens. Bioelectron. 15, 2000, 681-691.

[35] J.S Do, K.H Lin and R. Ohara, Preparation of urease/nano-structured polyaniline-Nafion/ $\mathrm{Au} / \mathrm{Al}_{2} \mathrm{O}_{3}$ electrode for inhibitive detection of mercury ion. J. Taiwan Inst. Chem. Eng. 42, 2011 662-668.

[36] N. Verma, K. Sachin, and K. Hardeep, Whole cell based disposable biosensor for Cadmium detection in milk, Advances in Applied Science Research, 2(6), 2011, 354-363.

[37] J. Wyszkowska, J. Kucharski, and W. Lajszner, The Effects of Copper on Soil Biochemical Properties and Its Interaction with Other Heavy Metals, Polish J. of Environ. Stud. 15 (6), 2006, 927-934.

[38] B. Krajewska, Urease immobilized on chitosan membrane;Inactivation by heavy metal ions, J Chem Tech Biotechnol, 52, 1991, 157-162.

[39] G. Shen, Y. Lu and J. Hang, Combined effect of heavy metals and polycyclic aromatic hydrocarbons on urease activity in soil. Ecotoxicol Environ Safety, 63, 2006, 474-480 